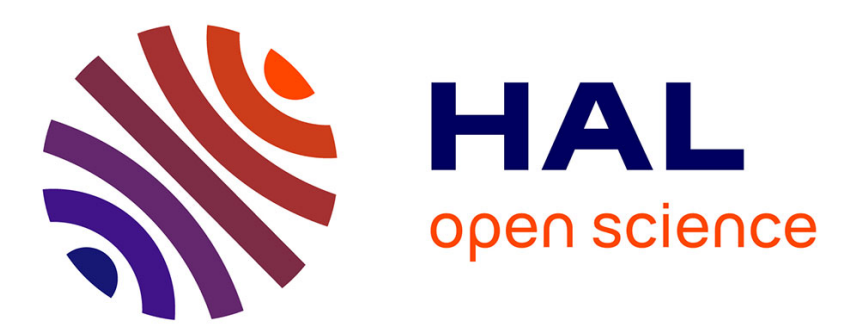

\title{
Bone histology of Iberosuchus macrodon (Sebecosuchia, Crocodylomorpha)
}

Jorge Cubo, Meike Köhler, Vivian de Buffrénil

\section{To cite this version:}

Jorge Cubo, Meike Köhler, Vivian de Buffrénil. Bone histology of Iberosuchus macrodon (Sebecosuchia, Crocodylomorpha). Lethaia, 2017, 19 (4), pp.495-503. 10.1111/let.12203 . hal-02295975

\section{HAL Id: hal-02295975 \\ https://hal.sorbonne-universite.fr/hal-02295975}

Submitted on 24 Sep 2019

HAL is a multi-disciplinary open access archive for the deposit and dissemination of scientific research documents, whether they are published or not. The documents may come from teaching and research institutions in France or abroad, or from public or private research centers.
L'archive ouverte pluridisciplinaire HAL, est destinée au dépôt et à la diffusion de documents scientifiques de niveau recherche, publiés ou non, émanant des établissements d'enseignement et de recherche français ou étrangers, des laboratoires publics ou privés. 
$6 \quad{ }^{1}$ Sorbonne-Universités, UPMC-Univ. Paris 06, CNRS, Institut des Sciences de la Terre de Paris

7 (ISTeP), 4 place Jussieu, BC 19, 75005 Paris, France

$8 \quad{ }^{2}$ ICREA, Pg. Lluís Companys 23, 08010 Barcelona, Spain.

$9{ }^{3}$ Institut Institut Català de Paleontologia Miquel Crusafont, Universitat Autònoma de Barcelona, 10 Carrer de les Columnes s/n, 08193 Cerdanyola del Vallés, Spain

$11{ }^{4}$ Museum National d'Histoire Naturelle, Centre de Recherche sur la Paléobiodiversité et les 12 Paléoenvironnements (CR2P), 75005 Paris, France

$14 *$ Corresponding author : jorge.cubo_garcia@upmc.fr

15

$16 \mathrm{RH}-$ Bone histology of Iberosuchus 
Iberosuchus macrodon is a Cenozoic crocodyliform interpreted as a terrestrial, cursorial form. In order to assess if this adaptation was accompanied by a high growth rate and an elevated resting metabolic rate (two features commonly attributed to several terrestrial Triassic Crocodylomorpha based on histology) we studied bone histology in the femora of two specimens attributed to $I$. macrodon. Beyond this question is the broader problem of the possible survival to the CretaceousPaleogene extinction event of tachymetabolic sauropsids other than birds. At mid-diaphysis, bone cortices in Iberosuchus are made of a parallel-fibered tissue that turns locally to true lamellar bone. Cortical vascularization consists of simple longitudinal canals forming a network of medium density. The spacing pattern of conspicuous lines of arrested growth suggests asymptotic growth for Iberosuchus. This general histological structure prevails also in the metaphyseal region of the bones. It is basically similar to that encountered in certain large lizards adapted to active predation, the

29 Varanidae and the Teidae. In one of the two Iberosuchus femora, however, an intra-cortical meniscus made of a tissue displaying a global radial architecture, occurs in the region of the fourth trochanter.

31 Histologically, the latter can be interpreted either as compacted spongiosa, or as a fibro-lamellar complex with a gross radial orientation, a tissue corresponding to fast periosteal apposition. These observations suggest that, Iberosuchus basically had a slow, cyclical growth indicative of an ectopoikilothermic, lizard-like, resting metabolic rate. However it might also have retained a limited capacity for fast periosteal accretion in relation to local morphogenetic requirements as, for instance, the development of crests or trochanters. structure, growth, metabolism. 
The presence of a four-chambered heart in crocodiles and birds (Seymour et al. 2004, Summers 2005) and unidirectional air flow through the lungs (Farmer \& Sanders 2010) suggests that the last common ancestor of archosaurs was endothermic, and that this character state was inherited by Ornithodira (pterosaurs and dinosaurs including birds) and Pseudosuchia (taxa more closely related to crocodiles than to birds), but was lost somewhere during the evolution of the latter (Seymour et al. 2004). Indirect evidence for this hypothesis has been gained from inferences of bone growth rates of extinct archosaurs (Ricqlès et al. 2008; Cubo et al. 2012; Legendre et al. 2013), assuming a direct relationship between bone growth rates and resting metabolic rates (Montes et al. 2007). Recently, resting metabolic rates of extinct archosaurs and non-archosaurian Archosauromorpha were inferred using bone paleohistology (Legendre et al. 2016), providing more direct support for that hypothesis. (Sebecidae and other Sebecosuchia such as Iberosuchus) forms survived the Cretaceous-Paleogene extinction event (Macleod et al. 1997). According to the null hypothesis, Iberosuchus retained resting metabolic rates similar to those of Triassic terrestrial Pseudosuchia with an upright stance, such as Terrestrisuchus (Ricqlès et al. 2003). Two alternative hypotheses will be tested: (1) The inferred cursorial locomotion (Riff \& Kellner 2011) of Iberosuchus suggests that it might have acquired even higher resting metabolic rates than its Triassic terrestrial relatives. (2) The Cretaceous-Paleogene extinction event filtered the diversity of Pseudosuchia, so that only taxa showing low resting metabolic rates survived. Bone histology has been acknowledged for several decades as one of the major clues for assessing the gross physiological adaptations of extinct taxa (Ricqlès 1974, 1978); unfortunately, there is no description of the histological features of long bones in notosuchians up to now (only osteoderms in some taxa were studied; cf. Buffrénil et al. 2015). In order to settle the question, we analyzed the bone histology of Iberosuchus, and tentatively interpreted it in terms of growth rates and metabolism activity. 
Paleocene of La Boixedat (Spain). These specimens belong to the paleontological collections of the Institut Català de Paleontologia (ICP), labeled IPS4930 and IPS4932. In contrast to the condition in the Eusuchia, the femora of Sebecus and Iberosuchus are (a) straighter and (b) the medial edge of the greater trochanter is a prominent, sharp, longitudinal crest (Pol et al. 2012). Although the specimens in this study cannot be attributed unequivocally to Iberosuchus (whose holotype is a skull fragment), the morphological congruence of available specimens nevertheless justifies the assumption that the scarce, non-neosuchian Meoseucrocodylia specimens from the Paleogene of the Iberian Peninsula and southern France are at least closely related, indistinguishable forms (Ortega et al. 1996). We follow the phylogeny of Pol et al. (2012) in which Neosuchia and Notosuchia are sister taxa and Iberosuchus is a sebecosuchian nested in Notosuchia.

After photography, the bones were embedded under vacuum in a polyester resin, and two transverse slices, $3 \mathrm{~mm}$ in thick, were removed from the middle of the diaphysis (Fig. 1A, B) and the base of the proximal metaphysis (Fig. 1E, F) of each femur. According to standard ground section procedures (e.g. Lamm 2013), these slices were polished on one side, glued on glass slides and grounded to a thickness $100 \mu \mathrm{m} \pm 20$. These thin sections were observed and photographed with a Nikon Eclipse E600POL microscope, under normal and cross-polarized light, with or without a lambda compensator.

Simple morphometric measurements were also performed on binary (black and white) images of the sections at mid-diaphysis (Fig. 1C, D) using the software Image J (Schneider et al. 2012). These measurements include: a) the compactness of each section, or GC (ratio, expressed in percent, of the area actually occupied by bone tissue to the total sectional area); b) compactness of the cortex proper, or CC (ratio, expressed in percent, of the actual area of the cortex occupied by bone tissue to the total cortical area, including bone plus cavities); c) the cortico-diaphyseal index, or CDi (mean thickness of bone cortex as a fraction of the mean diaphyseal radius). 
Both femoral diaphyses have a tubular morphology, with a free medullary cavity surrounded by a compact cortex. However, specimen IPS 4930, though smaller than IPS 4932 (38 \% less cross sectional area) is clearly more compact $(\mathrm{GC}=87.16 \%$ vs $77.52 \%)$ and has a thicker $(\mathrm{CDi}=0.65 v \mathrm{~s}$ $0.54)$ and more compact $(\mathrm{CC}=99.41 \%$ vs $79.06 \%)$ cortex. Perimedullary resorption is limited in this specimen; as a consequence bone layers deposited in early ontogenetic stages are preserved.

Histologically, the bone forming the diaphyseal cortex has similar characteristics in the two specimens. Most of its volume is predominantly composed of parallel-fibered tissue (Fig. 1A, B; Fig. 2A, B), displaying mass birefringence and collagen fiber bundles oriented circularly (i.e. parallel to the outer contours of the bones). In IPS 4932, this tissue can locally turn to the lamellar type (Fig. 2B). Frequent irregularities in the birefringence properties of the parallel-fibered bone suggest some degree of local variation in fiber orientation. Cell lacunae in this tissue are oriented parallel to the collagen fibers, and they display a small size, as compared to the lacunae occurring in primary or secondary endosteal deposits forming e.g. osteons (Fig. 2C).

The vascularization of the primary cortex mainly consists of simple vascular canals oriented longitudinally and, to a much lesser extent, obliquely. These canals are relatively few in the peripheral (outer) part of the cortex; especially in IPS 4932 (Fig. 2A, B). Vascular density increases in deeper cortical parts, a process much more pronounced in IPS 4930 (Fig. 1B; Fig. 2D) than in IPS 4932 (Fig. 1A). In both specimens, the cortical region bordering the medullary cavity has undergone Haversian remodeling. This process was relatively diffuse in IPS 4932, where it created sparse secondary osteons (Fig. 2C, E); it was more restricted but more intense in IPS 4930 where dense Haversian bone tissue was spatially limited (Fig. 2F). Superficial resorption/reconstruction processes of variable intensity also occurred around the medullary cavity, creating endosteal layers of secondary lamellar bone.

In both specimens the femoral cortex shows cyclical growth marks in the form of lines of arrested growth (LAGs). The latter appear as thin dark lines parallel to the contour of the bones (Fig. 2G). These lines are broadly, but unevenly, spaced in the depth of the cortex $(280 \mu \mathrm{m}$ in the average on Fig. 2G). In IPS 4932, the spacing of the LAGs suddenly becomes more regular and much narrower in the most peripheral cortical layers, where the intervals between consecutive LAGs drop to $78 \mu \mathrm{m}$ in the 
average (Fig. 2G). Both femora also have bundles of short Sharpey's fibers (length $50 \mu \mathrm{m} \pm 10$ )

122 oriented radially and obliquely (Fig. $2 \mathrm{H})$.

\section{Histology of the metaphyseal region}

The histological structure of primary periosteal cortices in the metaphyseal region of both specimens (Fig. 1E, F) is basically similar to that prevailing in the diaphyseal region: most of the cortical volume consists of parallel-fibered bone, the collagen fibers of which are oriented circularly (Fig. 3A, B). However, three main differences exist. 1) Bone vascularization, mainly represented by simple vascular canals and primary osteons oriented longitudinally, tends to be lower in the metaphyses than in the diaphyses, especially in IPS 4930 (Fig. 3A, B). 2) Loose networks of remodeled endosteal bone trabeculae (Fig. 1E, F; Fig. 3C) partly fill the medullary cavity (the medullary cavity is free in the diaphysis). 3) In IPS 4932, the cortex is not only composed of vascularized parallel-fibered tissue; but also contains a broad, central crescent-like meniscus formation displaying different histological features (Fig. 1F; Fig. 3D). This formation is briefly described below.

This peculiar bone layer is located under the forth trochanter of the femur and consequently, it occupies only a part of the sectional area (Fig. 1F). It is inserted in the middle of the cortex, between two layers (under and above it) of ordinary parallel-fibered bone (Fig. 3D). Histologically, the thinnest parts of this meniscus consist merely of some big longitudinal primary osteons (Fig. 3E). In its thicker part, the meniscus displays two components: 1) Multiple oblong areas made of brightly birefringent parallel-fibered tissue (blue in Fig. 3F, G) with a dominant, though variable, radial orientation (including for cell lacunae) and vascular canals also displaying a gross radial orientation. 2) Small and irregular monorefringent, or poorly birefringent areas, unevenly wedged between the birefringent ones, and formed by woven bone (red in Fig. 3F, G). They contain big multipolar cell lacunae.

This basic structure can be interpreted in two distinct ways. The first interpretation is that it represents former spongiosa, compacted by endosteal deposits. Crests, trochanters and other bone excrescences related to muscle insertion are most often associated with spongy tissues within bone cortices (e.g. Ricqlès 1976a). During growth, such spongiosae are frequently made compact by intertrabecular filling, a situation actually observed by one of us (VB) in sections of the fourth trochanter 
149 of this compacted spongiosa in IPS 4932 reflects the strong traction stress exerted on the periosteum 150 and the growing bone cortex by the muscle caudofemoralis (according to Wolf's law; cf. Currey

151 2002). An alternative interpretation of the meniscus structure is that it is made of a radiating fibro-

152 lamellar bone complex, a tissue known to be characteristic of fast or very fast accretion. The

153 monorefringent areas would represent the woven-fibered trabeculae initially deposited by the

154 periosteum. The brightly birefringent areas would be primary osteons. The main difference between

155 the bone forming the meniscus and typical fibro-lamellar complexes is that the highly ordered and

156 conspicuous periosteal scaffoldings of woven-fibered trabeculae that characterize these complexes

157 cannot be clearly identified in Iberosuchus. As a consequence, the limits and shape of the putative

158 primary osteons cannot be traced precisely. For this reason, the tissue forming the thick part of the

159 meniscus should be interpreted, with necessary caution, as an atypical form of radial fibro-lamellar

160 bone tissue. Both interpretations, compacted spongiosa vs radiating fibro-lamellar complex, differ

161 little from each other. In both cases, the differentiation of the fourth trochanter basically involves the

162 sub-periosteal accretion of a spongiosa, and its subsequent compaction by inter-trabecular, centripetal

163 deposits of endosteal lamellar or parallel-fibered tissue. Their main difference would reside in the

164 dynamics of bone deposits: fast or very fast periosteal and endosteal deposits in the case of a radiating

165 fibro-lamellar complex; much slower deposits in the case of a compacted spongiosa.

166 The basal part of the meniscus is in continuity (though histologically very distinct) with the

167 subjacent parallel-fibered tissue. Conversely, the peripheral border of the meniscus is marked by a

168 reversion line displaying a typical scalloped contour at high magnification (Fig. 3H). Above this line,

169 towards bone periphery, the parallel-fibered tissue prevails again. The occurrence of this reversion line

170 means that, during growth, the height of the basal part of the trochanter had to be reduced, through a

171 resorption process, to become compatible with the diameter of the diaphysis into which the trochanter

172 was sequentially relocated.

173 DISCUSSION 
175 parallel-fibered tissue with variable vascular density and conspicuous lines of arrested growth. This

176 situation was observed in all bone sections, especially those sampled at mid-diaphysis, i.e. a sectional

177 plane classically considered as a general reference for histological studies of long bones; e.g. Lamm

178 2013). This result strongly suggests that Iberosuchus was not a fast growing, tachymetabolic animal,

179 but a slow growing crocodile with steep, cyclic decreases in growth rate. Several experimental studies

180 indeed show that, on the one hand, bone tissue with scattered longitudinal vascular canals results from

181 accretion speeds less than $5 \mu \mathrm{m} /$ day (Castanet et al. 1996) and that, on the other hand, parallel-fibered

182 bone corresponds to accretion rates less than $1 \mu \mathrm{m} /$ day (e.g. Buffrénil \& Pascal 1984). The actual

183 apposition rate on the femoral cortex of Iberosuchus could have been between these values which are

184 anyway far below those prevailing for the woven-fibered tissue, especially when it contributes to the constitution of fibro-lamellar complexes (laminar, plexiform, radiating bone tissues) typically encountered in fast growing endotherms (Castanet et al. 1996, 2000; Margerie et al. 2002; see also

187 Cubo et al. 2012). In most modern crocodiles, the femoral cortex is made of a lamellar-zonal tissue 188 (Enlow \& Brown 1957, Ricqlès 1976b, Lee 2004) displaying conspicuous yearly growth cycles. The 189 latter consist of zones made of woven-fibered tissue (that may change to the parallel-fibered type), associated with annuli made of parallel-fibered or true lamellar bone (Buffrénil 1980a, b; Hutton

191 1986). These two components of an annual growth cycle are deposited sequentially and reflect a progressive decrease in growth rate that may end, each year, in a total cessation of growth and the 193 formation of a LAG (Buffrénil 1980a). Since it integrates a woven-fibered component, the lamellar-

194 zonal tissue reflects faster deposition than the mere parallel-fibered type prevailing in Iberosuchus.

195 The occurrence of lines of arrested growth in this taxon, as well as the absence of annuli, clearly 196 shows that the maximum growth rate in Iberosuchus was comparable to the slowest rates of modern crocodiles, and that growth stopped completely each year. As observable in the femur, the histological

198 features of Iberosuchus can be best compared to those of large predatory squamates such as the 199 varanids or the teids (e.g. Duarte-Varela \& Cabrera 2000, Buffrénil \& Hémery 2002, see also Cubo et 200 al. 2014). In both cases, bone cortices are made of parallel-fibered tissue (that may turn to the woven201 fibered type in the inner cortex) comprising longitudinal simple vascular canals or primary osteons, 
and lines of arrested growth. Therefore, if the histological structure of long bones indeed reflects

203 growth rate, as initially proposed by Amprino (1947) and universally acknowledged today, then the

204 growth activity of Iberosuchus should be considered similar to that of extent large lizards. This

205 comparison is further substantiated by the spacing pattern of cyclical growth marks in IPS 4932 .

206 Growth mark spacing indeed suggests that a sudden and steep decrease in growth activity occurred

207 about six years before this animal died. Its growth pattern was thus clearly asymptotic, a situation

208 commonly encountered in squamates in which epiphyseal and metaphyseal fusion limits growth

209 possibilities (Maisano 2008, Buffrénil et al. 2004). Conversely, this growth pattern is unusual in

210 crocodiles, though it was observed in some populations of Alligator mississippiensis (Woodward et al.

211 2011; see also Lee et al. 2013). IPS 4932 is larger than IPS 4930 and displays signs of a sudden

212 decrease in growth. These two characteristics indicate an older age for IPS 4932. Moreover, the

213 porosity of deep cortical layers in this specimen is a feature commonly encountered in mature

214 crocodilian females (Wink \& Elsey 1986; Wink et al. 1987).

215 If the general relationship between the histological structure of primary bone cortices and their

216 appositional rate is now strongly evidenced by experimental data (e.g. Castanet et al. 1996), the

217 association between, on the one hand, bone tissue types and growth rate and, on the other hand, the

218 resting metabolic rate of an organism, seems to be less simple and less clearly deciphered. Montes et

219 al. (2007) found a direct relationship between periosteal bone growth rate and resting metabolic rate in

220 a sample of growing amniotes. In general, long bone cortices made of parallel-fibered tissue, be it

221 vascularized or not, are characteristically encountered in ecto-poikilothermic tetrapods (e.g. Enlow and

222 Brown 1956-1958, Ricqlès 1976). However, the few extant large squamates displaying vascular canals

223 (simple canals or primary osteons) within parallel-fibered bone, i.e. the largest Teidae (Duarte-Varela

224 \& Cabrera 2000, Cubo et al. 2014) and the Varanidae more than $30 \mathrm{~cm}$ in snout-vent length (Buffrénil

225 et al. 2008), can experience transitory episodes of relatively high and constant metabolic rate during

226 either their reproductive cycle (Tattersall et al. 2016), or during times of intense foraging activity

227 (synthesis in Thompson 1999). Otherwise, these animals, including the largest ones, have a typical

228 ecto-poikilothermic physiology (Green et al. 1991, Christian \& Conley 1994, Wikramanayake et al. 
1999). The question is made more complex by the fact that the very same type of bone tissue

230 (vascularized parallel-fibered bone) can be observed in long bone cortices in some large anurans, such as Rana Catesbeiana, Rhinella marina, or Pipa pipa (pers. obs. VB), known to have much lower metabolic rates than the squamates in general (White et al. 2006 ). Such observations suggest that the actual relationship between the details of bone structure and the metabolic rate of an organism result

234 from a complex, multifactorial causality that needs to be fully deciphered. It nevertheless remains that 235 bone cortices mainly composed of parallel-fibered tissue are very unlikely to belong to an endotherm236 homeotherm animal. For this reason, the fundamental thermal regime of Iberosuchus should be 237 considered to have been ectotherm and poikilotherm, as is also the case for the large extant squamates 238 or lissamphibians mentioned above.

The particular case of Iberosuchus suggests that, in pseudosuchians, a terrestrial habitat is not

240 necessarily associated with a high, sustained growth speed and the tachymetabolic regime consistent

241 with it. Of course, this conclusion holds only for Iberosuchus. The Notosuchia (of which the

242 Sebecosuchia are but one clade) represent a particularly rich and diversified lineage of terrestrial forms 243 in which a number of bizarre and ecologically enigmatic taxa occur (e.g. Ortega et al. 2000). Future

244 comparative studies should document whether this high morphological diversity also involved significant physiological discrepancies.

One element in our observations could challenge the conclusion presented above: the possible 247 occurrence of radiating fibro-lamellar tissue in a limited area of the metaphyseal cortex of IPS 4932.

248 This type of bone tissue is considered to result from the fastest accretion rate (Margerie et al. 2004)

249 and is supposed to be an exclusive feature of fast-growing tachymetabolic tetrapods (Ricqlès 1974,

250 1976a). For several reasons, the occurrence of radiating fibro-lamellar tissue in the core of the 251 metaphyseal cortex cannot be alleged to conclude that (1) episodes of fast growth occurred in the life 252 of IPS 4932, and (2) that this taxon had the physiological competence for sustaining them at the level 253 of the organism as a whole. As mentioned in the observations, the identification of this tissue is 254 debatable, due to atypical histological characteristics. Nevertheless, even if the tissue forming the 255 meniscus is really akin to fibro lamellar radiating bone, the complete lack of this tissue in diaphyeal 
cortices (despite the excellent preservation of primary cortical tissues) would clearly indicate that its

257 occurrence in the proximal metaphysis of IPS 4932 does not indicate a general trend towards fast

258 growth in Iberosuchus, but a local, topographically restricted, process. This taxon might indeed have

259 retained the potential capacity to develop fast periosteal accretion but, in the specimen studied here,

260 this capacity would have been expressed in a strictly local context, in relation to the differentiation,

261 growth and sequential relocation of the fourth trochanter during ontogeny.

With reference to the hypotheses listed in the introduction, our results suggest that the situation

263 may be more complex than expected because some crocodyliforms might have preserved

264 physiological potentialities that could have been expressed, or non-expressed, depending on

265 morphological and/or ecological contexts. Future studies based on larger samples should settle more

266 firmly this interesting question, and help assess if the capacity for fast growth, at least in limited

267 skeletal regions and for a limited duration, is a frequent feature in the Notosuchia.

\section{LITERATURE CITED}

Amprino, R. 1947: La structure du tissu osseux envisagée comme expression de différences dans la vitesse de l'accroissement. Archives de Biologie 58, 315-330.

271 Antunes, M.T. 1975: Iberosuchus, crocodile Sébécosuchien nouveau, de l'Eocène ibérique au Nord 272 de la Chaîne centrale, et l'origine du canyon de Nazaré. Comunicaçoes dos Servicios Geologicos de 273 Portugal 59, 285-330.

Antunes, M.T. 1986: Iberosuchus et Pristichampsus, crocodiliens de l'Eocène : données complémentaires, discussion, distribution stratigraphique. Cièncias da Terra 8, 111-122.

Buffrénil, V. de. 1980a: Données préliminaires sur la structure des marques de croissance squelettiques chez les crocodiliens actuels et fossiles. Bulletin de la Société Zoologique de France $105,355-361$.

Buffrénil, V. de. 1980b: Mise en évidence de l'incidence des conditions de milieu sur la croissance 280 de Crocodylus siamensis (Schneider, 1801) et valeur des marques de croissance squelettiques pour 281 l'évaluation de l'âge individuel. Archives de Zoologie Expérimentale et Générale 121, 63-76. 
Buffrénil, V. de \& Pascal, M. 1984: Croissance et morphogenèse postnatales de la mandibule du vison (Mustela vison Schreiber) : données sur la dynamique et l'interprétation fonctionnelle des dépôts osseux mandibulaires. Canadian Journal of Zoology 62, 2026-2037.

Buffrénil, V. de \& Castanet, J. 2000 : Age estimation by skeletochronology in the Nile monitor (Varanus niloticus), a highly exploited species. Journal of Herpetology 34, 414-424.

Buffrénil, V. de \& Hémery, G. 2002: Variation in longevity, growth, and morphology in exploited

Nile monitors (Varanus niloticus) from sahelian Africa. Journal of Herpetology 36, 419-426.

Buffrénil, V. de, Ineich, I. \& Böhme, W. 2004: Comparative data on epiphyseal development in the family Varanidae. J. Herpetology 37, 328-335.

Buffrénil, V. de, Clarac, F., Fau M., Martin, S., Martin B., Pellé, E. \& Laurin, M. 2015: Differentiation and growth of bone ornamentation in vertebrates: a comparative histological study among the Crocodylomorpha. Journal of morphology 276, 425-445.

294 Castanet, J., Grandin, A., Abourachid, A., \& Ricqlès, A. de. 1996: Expression de la dynamique de croissance dans la structure de l'os périostique chez Anas platyrhynchos. Comptes-Rendus de. L'Académie des Sciences, Paris, Sciences de la Vie 319, 301-308.

Castanet, J., Curry-Rogers, K., Cubo, J. \& Boisard, J-J. 2000: Periosteal bone growth rates in extant ratites (ostrich and emu). Implications for assessing growth in dinosaurs. Comptes-Rendus de. L'Académie des Sciences, Paris, Sciences de la Vie 323, 543-550.

Christian, K.A. \& Conley, K.E. 1994: Activity and resting metabolism of varanid lizards compared with "typical” lizards. Australian Journal of Zoology 42, 185-193. growth rate in extinct archosaurs. Paleobiology 38, 335-349. constraints on bone vascular supply in diapsids. Biological Journal of the Linnean Society of London $112,668-677$. 
(Tupinambis merianae) of known ages. Herpetologivcal Review 31, 224-226.

309 Enlow, D.H. \& Brown, S.O. 1957: A comparative histological study of fossil and recent bone tissues. Part II. Texas Journal of Science 9, 186-214. $327,338-340$. energetics of free-ranging Komodo dragons, Varanus komodoensis. Comparative Biochemistry and Physiology 99A, 97-101.

Hutton, J.M. 1986: Age determination of living Nile crocodiles from the cortical stratification of bone. Copeia 1986(2), 332-341.

Lamm, E-T. 2013: Preparation and sectioning of specimens. In Padian, K., Lamm, E.-T. (eds): Bone Histology of Fossil Tetrapods, 55-160. University of California Press, Berkeley. mississippiensis. Journal of Anatomy 204, 197-207.

Legendre, L.J., Segalen, L. and Cubo, J. 2013: Evidence for high bone growth rate in Euparkeria obtained using a new paleohistological inference model for the Humerus. Journal of Vertebrate Paleontology 33, 1343-1350. ancestral high metabolic rate in archosaurs. Systematic Biology 65, 989-996. 265-292. 
334 Margerie, E. de, Cubo, J. \& Castanet, J. 2002: Bone typology and growth rate: testing and quantifying « Amprino's rule » in the mallard (Anas platyrhynchos). Comptes-Rendus de. L'Académie des Sciences, Paris, Sciences de la Vie 325, 221-230. relationship between bone microstructure and growth rate: a fluorescent labelling study in the king penguin chick (Aptenodytes patagonicus). Journal of Experimental Biology 207, 869-879. between bone growth rate, body mass and resting metabolic rate in growing aminotes: a phylogenetic approach. Biological Journal of the Linnean Society 92, 63-76.

Ortega, F., Buscalioni, A.D. and Gasparini, Z. 1996: Reinterpretation and new denomination of Atacisaurus crassiproratus (Middle Eocene; Issel, France) as cf Iberosuchus (Crocodylomorpha, Metasuchia). Geobios 29, 353-364.

Ortega, F., Gasparini, Z., Buscalioni, A.D. and Calvo, J.O. 2000: A new species of Araripesuchus (Crocodylomorpha, Mesoeucrocodylia) from the Lower Cretaceous of Patagonia (Argentina). Journal of Vertebrate Paleontology 20, 57-76. Paleontology 32, 328-354. 80.

Ricqlès, A. de. 1976a: Recherches paléohistologiques sur les os longs des tetrapods. VII. - Sur la classification, la signification fonctionnelle et l'histoire des tissus osseux des tetrapodes. Annales de 
Ricqlès, A. de. 1976b: On bone histology of fossil and living reptiles, with comments on its

358 functional and evolutionary significance. In Bellairs, A. d'A. \& Cox, C.B. (eds) Morphology and Biology of Reptiles, 123-150. Linnean society Symposium Series n³, London.

Ricqlès, A. de. 1978: Recherches paléohistologiques sur les os longs des tetrapods. VII. - Sur la classification, la signification fonctionnelle et l'histoire des tissus osseux des tétrapodes (troisième partie). Annales de Paléontologie 64, 85-111. pseudosuchian archosaurs and related taxa. Annales de Paléontologie 89, 67-101. archosaurs and their ancient relatives: Complementary histological studies on Triassic archosauriforms and the problem of a "phylogenetic signal" in bone histology. Annales de Paléontologie 94, 57-76.

Riff, D. and Armin Kellner, A.W. 2011: Baurusuchid crocodyliforms as theropod mimics: clues from the skull and appendicular morphology of Stratiotosuchus maxhechti (Upper Cretaceous of Brazil). Zoological Journal of the Linnean Society 163, S37-S56.

Schneider, C.A. Rasband, W.S. and Eliceiri, K.W. 2012 : NIH Image to ImageJ: 25 years of image analysis. Nature methods 9(7), 671-675.

Seymour, R.S., Bennett-Stamper, C.L., Johnston, S.D., Carrier, D.R. and Grigg, G.C. 2004: Evidence for endothermic ancestors of crocodiles at the stem of archosaur evolution. Physiological and Biochemical Zoology 77, 1051-1067.

Summers, A.P. 2005: Evolution - Warm-hearted crocs. Nature 434, 833-834.

Tattersall, G.J., Leite, C.A.C., Sanders, C.E., Cadena, V. ,Andrade, D.V., Albe, A.S., Milson, W.K. 2016 : Seasonal reproductive endothermy in Tegu lizards. Scientific Advances 2016 ; e1500951. 

mississippiensis. Journal of Morphology 189, 183-188.

Wink, C.S., Elsey; R.M. \& Hill, E.M. 1987: Changes in femoral robusticity and porosity during the reproductive cycle of the female Alligator (Alligator mississippiensis). Journal of Morphology 193: $317-321$.

White, C.R., Phillips, N.F., Seymour, R.S. 2006 : The scaling and temperature dependence of vertebrate metabolism. Biology Letters 2, 125-127.

Wikramanayake, E.D, Ridwan, W. \& Marcellini, D. 1999 : The thermal ecology of free-ranging Komodo dragons, Varanus komodoensis, on Komodo Island, Indonesia. In Horn, H.-G. \& Böhme, W. (eds.) Advances in monitor research II. - Mertensiella 11, 157-166. growth in the American alligator. Journal of Herpetology 45, 339-342.

\section{ACKNOWLEDGEMENTS}

We thank Francisco Ortega for his valuable help in performing the taxonomic assignment of the samples analyzed to Iberosuchus. We would like to express our gratitude to an anonymous reviewer for his/her helpful comments and to an associate editor for his/her stylistic suggestions. This work was supported by the Spanish Ministry of Economy and Competitiveness: CGL2015-63777-P, PI: MK, and 2014 SGR 1207, PI: MK, and CERCA Programme / Generalitat de Catalunya. We have no conflict of interest to declare.

\section{FIGURE LEGENDS}

$404 \quad$ Figure 1: Gross aspect of the sections.

A: Global aspect of the the mid-diaphyseal section in IPS 4930. B: Global aspect of the the middiaphyseal section in IPS 4932. C: Binary image of the mid-diaphyseal section in specimen IPS 4930. 
D: Binary image of the mid-diaphyseal section in specimen IPS 4932. E: Global aspect of the the metaphyseal section in IPS 4930. F: Global aspect of the metaphyseal section in IPS 4932. Scale bar: 2 $\mathrm{mm}$.

Figure 2: Bone histology in the femoral diaphysis in IPS 4930 and 49832.

A: Peripheral cortex of the femur in IPS 4930. The upper part is viewed in transmitted polarized

412 light with lambda compensator; the lower part in ordinary transmitted light. B: Peripheral cortex of the

413 femur in IPS 4932. Upper part: transmitted polarized light with lambda compensator; lower part:

414 ordinary light. C: Size of osteocyte lacunae in periosteal and endosteal deposits (IPS 4932). The insert

415 is a closer view at the wall of a secondary osteon as compared to the primary periosteal cortex. D:

416 vascular density in the deep, peri-medullary cortex of IPS 4930. E: Secondary osteons scattered in the 417 cortex of specimen IPS 4932. Polarized light. F: Localized area of dense Haversian tissue around the 418 medullary cavity in IPS 4930. G: Lines of arrested growth, or LAG (arrows) in the cortex of IPS 4932. 419 Note the tight spacing of the last LAGs. H: Sharpey's fibers in the cortex of IPS 4930 (arrows). All 420 scale bars are equal to $0.5 \mathrm{~mm}$ but that of the close-up in $\mathrm{C}$, which equals $0.1 \mathrm{~mm}$.

421 Figure 3: Histological characteristics of the metaphyseal region.

422 A: Basic appearance of the femoral cortex in the metaphyseal region of IPS 4930. Upper part:

423 transmitted polarized light with lambda compensator; lower half: ordinary transmitted light. B:

424 Femoral cortex in the metaphyseal region of IPS 4932. Upper part: transmitted polarized light with

425 lambda compensator; lower half: ordinary transmitted light. C: Remodeled endosteal trabeculae 426 occupying the medullary cavity in the metaphysis of IPS 4930. Polarized light. D: Complex cortical 427 structure observed locally in the metaphyseal of IPS 4932. The inner (left) and the outer (right) parts 428 of the cortex are formed by parallel-fibered bone, the collagen fibers of which are oriented circularly 429 (yellow). In between these layers the cortex is occupied by a tissue with a dominant radial 430 structuration. E: Longitudinal primary osteons in the thin extremities of the crescent-like meniscus.

431 Polarized light. F: Complex histological organization in the thick parts of the meniscus. Brightly 432 birefringent (here in blue) and poorly birefringent (here in red) areas oriented radially are unevenly 433 inter-mixed. Polarized light with lambda compensator. G: Continuity of the basal, parallel-fibered part 
434 of the cortex (bottom part of the picture) with the tissue forming the meniscus. Polarized light with 435 lambda compensator. H: Reversion line (RL) separating the meniscus and the peripheral layer of 436 parallel-fibered bone tissue. The insert shows the typical scalloped contour of the reversion line. All 437 scale bars are equal to $0.5 \mathrm{~mm}$ but that of the close-up in $\mathrm{H}$, which equals $0.1 \mathrm{~mm}$. 
A

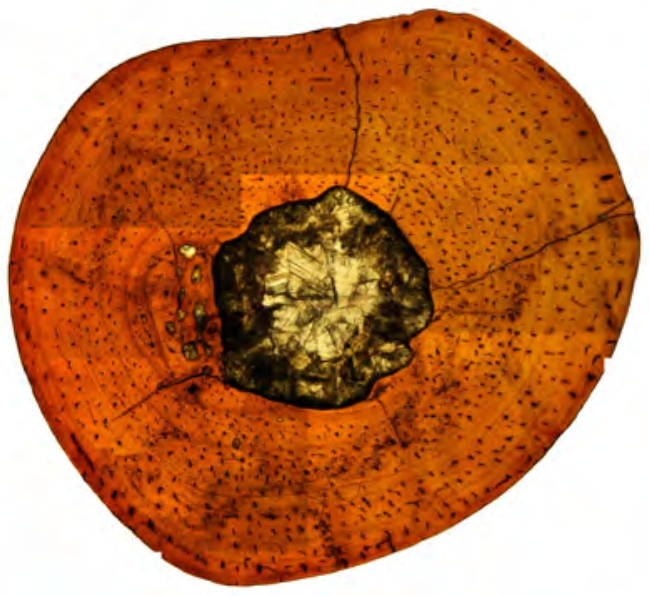

C
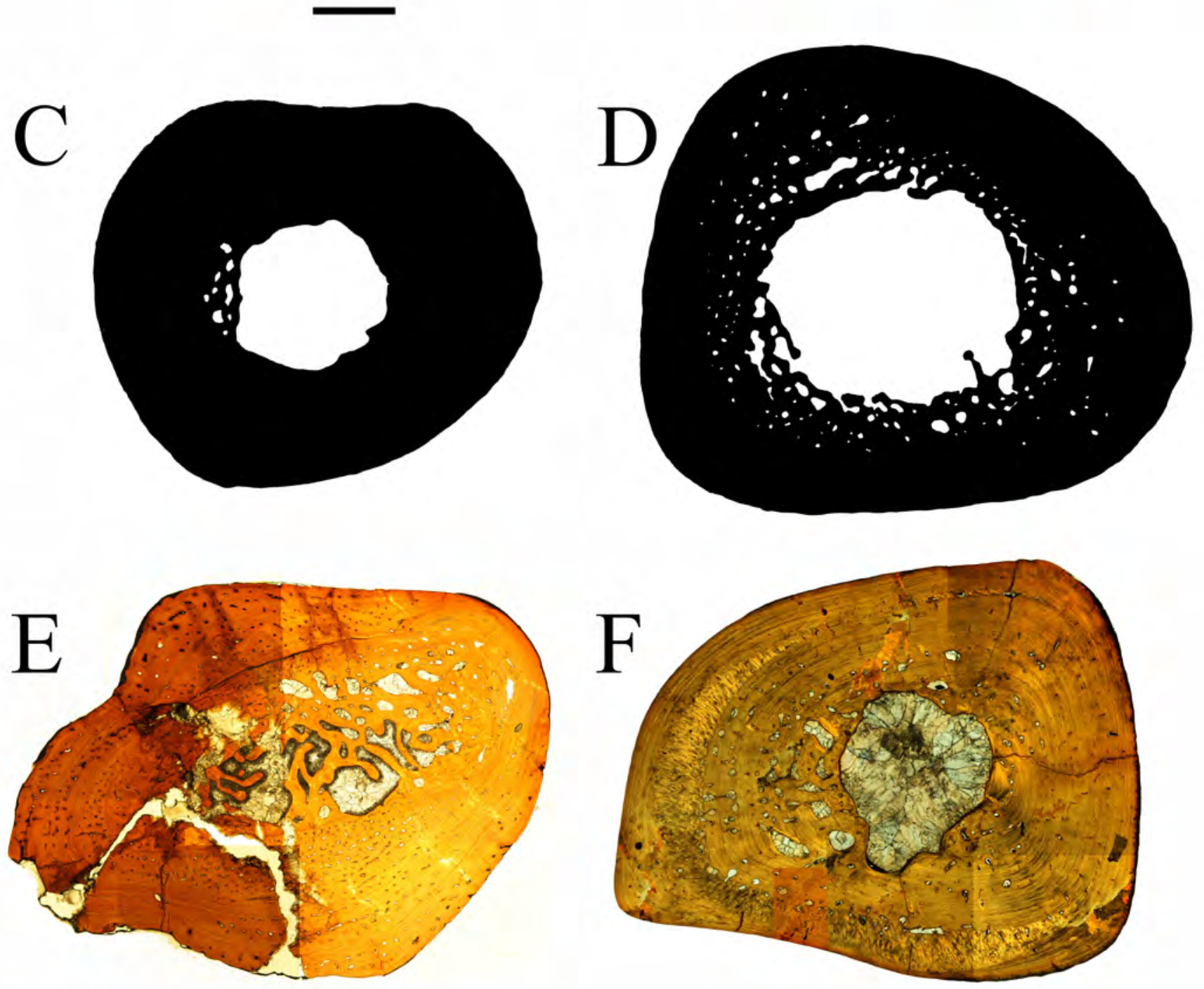


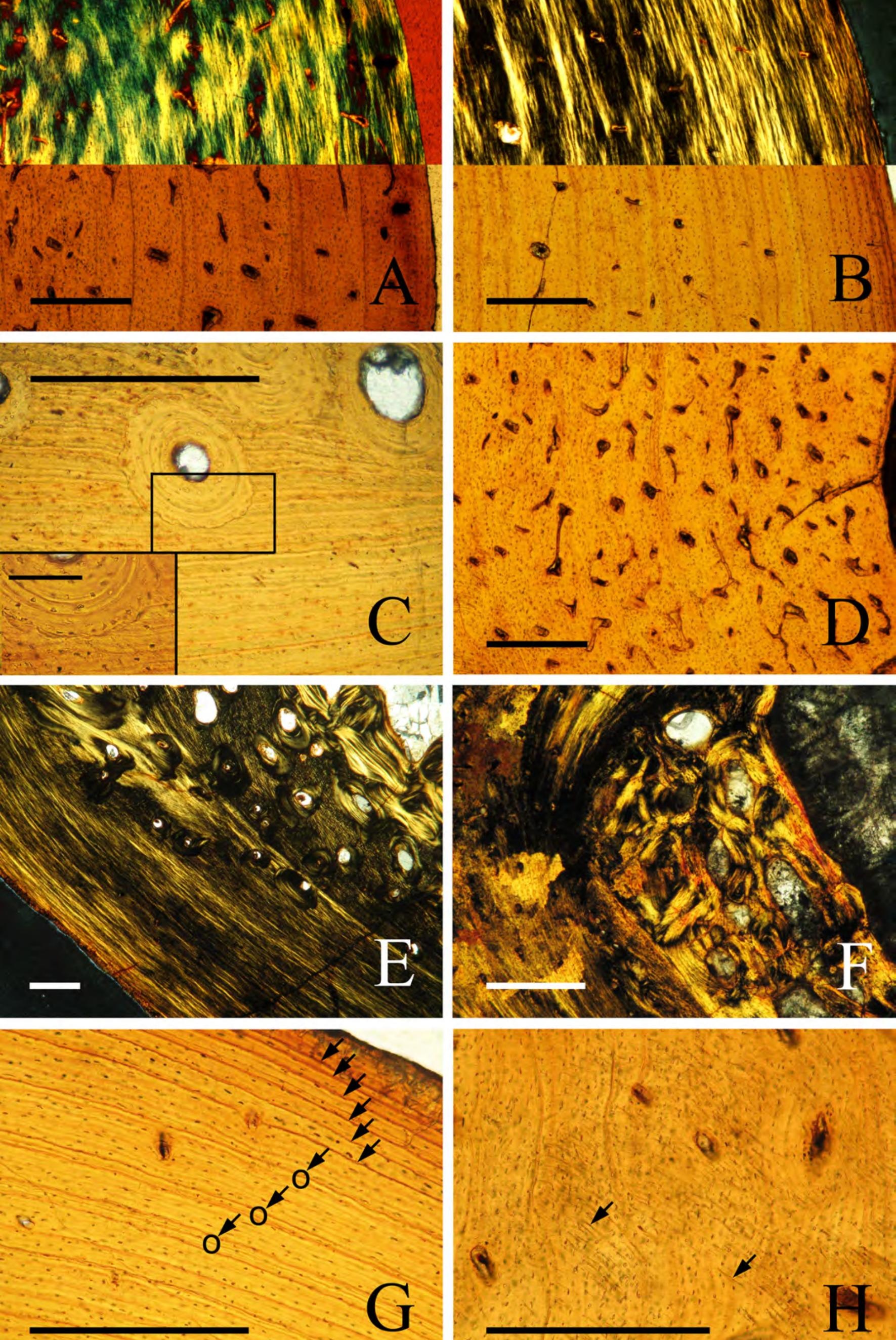



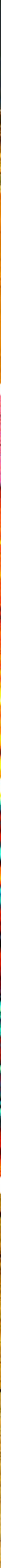